\title{
Interactive comment on "Sea ice led to poleward-shifted winds at the Last Glacial \\ Maximum: the influence of state dependency on CMIP5 and PMIP3 models" by Louise C. Sime et al.
}

\section{Louise C. Sime et al.}

Isim@bas.ac.uk

Received and published: 29 July 2016

We thank the three anonymous reviewers for the constructive and insightful reviews, and for their time. All reviewer comments are addressed in the attached PDF document.

Please also note the supplement to this comment: http://www.clim-past-discuss.net/cp-2016-43/cp-2016-43-AC1-supplement.pdf 